\title{
THE PIG OR THE STYE: DRINK AND POVERTY IN LATE VICTORIAN ENGLAND
}

Is it the pig that makes the stye or the stye that makes the pig? That is - is the dirt and drinking habits of the lower class the cause or consequence of living in overcrowded buildings?

Royal Commission on Working Class Housing, 1884-1885

In the last third of the nineteenth century, the relationship of poverty and drunkenness became a topic of bitter social controversy. The debate often had hopelessly polarized positions, being reduced in crudest form to a disagreement over whether poverty caused intemperance or the reverse. The very emotionalism and repetition of the argument, while disappointing to the logician, was a clear sign of the deep passions that the question invoked. While contributors to this debate stretched across the spectrum of religious and political alignment, the controversy was essentially the creature of the left. As will be argued, the question of self-inflicted poverty through drunkenness excited the Liberal and emergent socialist-labour parties far more than it did the Conservative-Unionist sector.

The debate over the causal relationship of drink and indigence stood as a significant milestone in the basic reassessment of poverty in late Victorian Britain. Substantial segments of opinion within both the Liberal Party and the socialist movement labelled the notion of selfinflicted poverty a vicious fiction, charging that capitalist society must accept its fundamental responsibility for the moral degradation of the working class. On the other hand, the interpretation of poverty as a moral failing not only drew wide support from within the Gladstonian party but also from the leadership of the Independent Labour Party and the trade union movement. The strength of the "moral" interpretation of poverty provides clear testimony to the evangelical roots of many late Victorian working class leaders.

The debate over self-inflicted poverty focused upon the vice of the working class - upon its gambling and sexual immoralities - but above all upon its drinking habits. Evangelical newspapers, such as the Temperance Star, bemoaned an increasingly permissive social climate:

"The catch concerts, obscene dances, Ethiopian troupes, and all 
the paraphernalia of what is most ensnaring to the inexperienced have not been without their effect upon the rising generation."1

By the last third of the century, a belief in self-caused poverty had become an article of faith for many educated Victorians. The concept of self-inflicted poverty both erected a powerful barrier against strenuous governmental action on the Condition of England question and buttressed that peculiarly Victorian belief in respectability.

Certainly the concept of self-inflicted poverty was not a late Victorian creation; the belief that much of poverty was due to self-choice had found expression since the Tudor Poor Laws. In 1815 the economist Patrick Colquhoun subdivided the pauper population of England into two categories, "innocent" and "culpable". "Innocent indigence" was the product either of physical informity (old age, blindness, etc.) or of the normal fluctuations of the economy; in either case of "culpable indigence", society should restrain any impulse to charity. Rather, the "culpable" poor should be constrained by legislation which recognized the danger of:

"this noxious class of the community, whose numbers have become exceedingly burthensome and alarming occasioning a vast pressure on the more virtuous and industrious classes of the people."2

In the last third of the nineteenth century, the concept of selfinflicted poverty suddenly attained new importance for several reasons. The intemperance of the working class, which had so irritated Colquhoun, had acquired a more terrifying dimension by the 1870's. Enfranchisement of the workingman seemingly had not brought a commensurate increase in his respectability. Some of those enfranchised by the 1867 and 1884 Reform Acts were felt to be in the category of what G. B. Shaw would later term the "undeserving poor". Secondly, the high levels of alcoholic consumption by the laboring classes seemed to explain both the commercial stagnation of the "Great Depression" and the survival of extensive poverty. And finally, the belief in selfinflicted poverty sustained the value system of respectability against the emergent socialist movement.

The most powerful force publicizing the existence of self-inflicted poverty was the temperance movement. The importance of the temperance crusade in Victorian social and political history has only be

1 Temperance Star, December 4, 1868, p. 352. The actual phrase "self-inflicted poverty" was coined by G. R. Porter, the founder (1833) of the Statistical Department of the Board of Trade.

2 Patrick Colquhoun, A Treatise on the Wealth, Power and Resources of the British Empire (London, 1815), p. 113. 
recognized in the last two decades. As George Kitson Clark has argued, mass intemperance was the visible fact of mid-Victorian social life. ${ }^{1}$ Drink consumption figures were enormous; in 1876 per capita consumption of beer was 34.4 gallons - the highest figure for the century. ${ }^{2}$ The moderate temperance writers, Joseph Rowntree and Arthur Sherwell, estimated that the typical working class family spent onefifth of its annual income on alcohol. ${ }^{3}$

The temperance movement drew heavily upon evangelical roots for its condemnation of alcohol. However, the prohibitionists also saw the drink question as an economic and political matter as well as a moral question. There was widespread fear within the temperance movement that unless the working man was quickly brought into respectable paths, the fabric of British democracy would decay. For the prohibitionists, and for many beyond their circle, the concept of self-inflicted poverty lay at the root of the social question. Drunkenness served the temperance movement as the unexamined first premise of its social analysis; ironically, many within the socialist movement would accept the contention that intemperance was the fundamental cause of poverty. It must be cautioned that British socialists were by no means united on the question of working class vice - for a substantial portion of the movement continued to blame the worker for both his inebriation and his poverty. Other segments, such as the Fabian Society or H. M. Hyndman's Social Democratic Federation, remained disdainfully aloof from the controversy, feeling the debate on self-inflicted poverty was beneath their analytic dignity.

Recent scholarship has argued with persuasion that the effects of the "Great Depression" upon British industry, and even upon some segments of British agriculture, have been highly exaggerated. But while revision has been able to separate the catastrophic myth from reality, it has not been able to dislodge the conviction of the late Victorians themselves that a commercial tragedy had occurred - that the economic time was somehow out of joint. Explanation of this break in the tradition of expected progress presented Victorian economists with a substantial challenge.

In the welter of contemporary confusion as to the causes of the

1 George Kitson Clark, The Making of Victorian England (London, 1964), p. 126. Dr Brian Harrison's Drink and the Victorians provides a thorough account of the temperance question in the 1830-1870 era. The Rev. Henry Carter's The English Movement (London, 1933), although now superseded by Harrison's work in many respects, remains the best account of the formation of the prohibitionist movement in the 1830's.

2 George Wilson, Alcohol and the Nation (London, 1940), p. 332.

${ }^{3}$ Joseph Rowntree and Arthur Sherwell, The Temperance Problem and Social Reform (London, 1899), p. 15. 
Great Depression, the prohibitionist explanation was remarkable for its clarity if not necessarily its profundity. The prohibitionists diagnosed the commercial slump as a reality tax which the heavy drinking habits of the working man had created. Underlying the prohibitionist argument dwelt a conviction that the productivity of the English worker was dropping because of his drunkenness. Benjamin Whitworth, cotton manufacturer and prohibitionist spokesman, contended that less than one-quarter of his work force was sober on Monday morning. "Saint Monday" was eroding the competitive edge of British capitalism, "Was it not a disgrace that after a Sunday of rest, they should devote the Monday in drinking."

The social background of the prohibitionist leadership gave them an economic reason for backing the concept of self-inflicted poverty. The hierarchies of the leading prohibitionist societies were almost completely dominated by Midlands manufacturers, many of whom featured themselves as self-made men. Abstinence became a retroactive explanation for their own accomplishment: virtue and selfinterest blended and became indistinguishable.

Temperance men were of overwhelmingly non-conformist and mercantile backgrounds - politically different men from the basically urban and Anglican leaderships of both major parties. The Methodist A. J. Balfour was a vice-president of the most powerful temperance society, the United Kingdom Alliance. W. S. Caine, member of a family of Liverpool iron merchants, was himself a wealthy partner in Shaw Brothers Iron Company. Caine was a Congregationalist, a Vice President of the Alliance, and President of the smaller National Temperance League. The Congregationalist Samuel Morley owned the clothing firm of I. and R. Morley. Hugh Mason, Thomas Whittaker, and Benjamin Whitworth were all prominent industrialists and members of the United Kingdom Alliance. Whitworth was one of the largest contributors to the UKA; his annual gift ran between $£ 600$ and $£ 1000$. The president of the Alliance, Sir Wilfred Lawson, was a Cumberland squire, and one of the few exceptions to the concentration of industrialists within the temperance leadership. Neither the commercial background nor the ideology of the prohibitionists disposed them to find basic fault with British capitalism.

Acceptance of the "moral" explanation of poverty was not limited

1 Alliance News, March 4, 1871, p. 142. On the general subject of British productivity, H. J. Habakkuk's American and British Technology (Cambridge, 1962) is invaluable. Donald McCloskey's "Did Victorian Britain Fail?", in: Economic History Review, Second Series, Vol. XXIII (1970), argues persuasively that the relative slippage of the British economy after 1870 was due to natural economic forces and not to any decline in the savings ratio. 
to abstainers. While the percentage of abstainers in the House of Commons was never higher than $10 \%$ during this period, there was, nonetheless, widespread agreement with the prohibitionist diagnosis of poverty. Even Tory politicians occasionally expressed horror at the sums which the workingman spent on drink; Randolph Churchill declared in 1890 that liquor was responsible for half of the crime and two-thirds of the poverty of England. ${ }^{1}$

The temperance message to the working class was a curious mixture of paternal and individualist strands. Paternal, because the prohibitionists believed their bourgeois norms to be an absolute; they regarded their natural constituency as being the "respectable" poor. ${ }^{2}$ But individualistic in the sense of the insulation and social distance when the working class remained inebriated. In a sense, the belief in selfinflicted poverty was merely the concept of self-help turned sour. The ideology of the temperance industrialists thus provided them with an explanation of poverty which satisfied both their commercial woes and their evangelical feelings about poverty.

Mid-Victorian temperance had placed a high premium upon individualism. Joseph Livesey and John Bright, the two most famous exponents of mid-century temperance, worked resolutely against legislative interference with alcoholic habit - for their enemy was not the public house but the thriftless and drunken habits of the nonrespectable working class. Accordingly, mid-century temperance spokesmen regarded the worker as an independent entity, culturally able to make his own choice - and morally responsible for his fate if he refused to adopt "middle class" norms of respectability, temperance, and thrift.

By the last quarter of the nineteenth century, the temperance movement had lost its faith in social mobility. Lamarckian biology seemingly implied that class differences would widen because of inherited characteristics. The prohibitionists considered alcohol to be "brain poison". Alcoholism could be transmitted by heredity, with a resultant deterioration in each successive generation. Eventually, alcoholism was self-destructive: "Nature's design in this is that the disease should work its own end by resulting in the surcease of the tainted family."3 But the prohibitionists feared that by this time, incurable harm would

1 Randolph Churchill to W. H. Harcourt, July 26, 1890, Harcourt Papers, Stanton Harcourt, Box 3.

2 Cardinal Manning Notebook, n.d., Manning Papers, St Mary of the Angels, London, Box 4. For the basic positions on the spreading controversy on the labor aristocracy question, see E. J. Hobsbawm, "The Labour Aristocracy in Nineteenth Century Britain", in Labouring Men (New York, 1964), and Henry Pelling, Popular Politics and Society in Late Victorian England (London, 1968).

${ }^{3}$ W. J. Lacey, The Case for Total Abstinence (London, 1899), p. 108. 
have been done to the texture of British politics. The late Victorian temperance movement was generally opposed to the development of class politics, fearing that this would undercut the whole cult of respectability.

The paternalism of the teetotal position was always close to the surface. Prohibitionists commented frequently upon the contrast between the interest of the educated classes in the Empire and their ignorance of the British slums. Wilfred Lawson bemoaned the concern of the Salisbury government to establish liquor-free areas in its Pacific colonies. Lawson argued that temperance must begin at home: "It would seem, however, that charity began in the Fiji Islands and had not yet reached here yet."1

While the prohibitionist leaders reserved their maximum censure for the working class drunkard, on occasion they accused the landed classes of having cynically allowed the drink problem to worsen. Central to the ideology of the temperance movement was its conviction that an aristocratic conspiracy existed to inebriate the workingman. Lawson contended that the "men in authority" feared the prohibitionist movement for its potential benefit for the working class - "that the swells did not want the people to rise". Lawson felt that the upper classes sanctioned the public house only to raise indirect taxation. The licensing system was therefore nothing but the tax dodge of the aristocracy:

"I would say naturally that all this money ought to be raised from property, from the riches of the country. Not so. These ingenious statesmen have hit on a very ingenious way of getting money out of the pockets of the people, and that is by setting traps for them. You have heard of savings banks for the people. These are the gin palaces, the public houses, and the beer houses." 2

Although most prohibitionists described social equality as a principle both inevitable and desirable, they were appalled by the possibility that the working class might try to achieve equality through the ballot box rather than through self-improvement. T. P. Whittaker (Alliance member and Liberal MP for Spen Valley, Yorkshire) argued that the watchword of modern politics would be equality - and that only prohibition could move that principle into safe channels:

"We have got to level up or level down. Things are going to be equally shared, and it is for you wealthy men in these industrial

1 Hansard, April 24, 1888, Third Series, Vol. CCCXXV, c. 414.

${ }^{2}$ Lawson at Exeter Hall, February 22, 1887, cited in Alliance News, February 26,1887, p. 141 . 
centres to make up your mind whether it is to be up or down. I want to suggest to you tonight that one of the ways to make levelling up is to deal with the greatest curse under the sun."1

In terms of economic doctrine, the prohibitionist camp regarded itself as the defender of Ricardian economics against the anarchic influences of laissez-faire. The neglected laws of classical economics had to be restudied; the Manchester School's gospel of a minimal state had proved disastrous to England's morality and thereby to its economy. In their condemnation of laissez-faire, the prohibitionists never advocated a general principle of interference with property rights. Rather, they equated laissez-faire with moral permissiveness and insisted that private immoralities, even if not directly harmful to others, nonetheless, came within the reach of state policy.

In their view, adherence to laissez-faire had permitted a serious diversion of working class spending patterns from "legitimate consumption" into alcohol. Intemperance was draining the wage fund, with the predictable result of depression. Only abstinence could reverse the trend. The temperance camp made frequent reference to Henry Fawcett's popular Interpretation of Political Economy. Fawcett had argued that labor was paid out of the wage fund and that the savings of any segment of society would increase the fund. But conversely, the dissipation of savings by any sector would decrease the wage fund and send the economy spiralling downward to depression.

The prohibitionists thus regarded working class discontent as a basically hypocritical desire to shift the responsibility for their poverty onto the shoulders of others. The social deadlock was obvious; drink was increasing the class war and was making revolution possible. An Alliance Newes editorial on the coal strike of 1894 suggested that few among the propertied classes had considered the real implication of the strike - the fact that between 200,000 and 300,000 people were willing to expose their own families to starvation. The moral was obvious; something was terribly wrong with the state of labor relations. ${ }^{2}$ The editorial concluded that this terrifying example of industrial strife would probably never have existed but for the workingman's reliance upon "brain poison".

The teetotaler's position was that only abstinence offered a solution to the class war. They regarded socialist complaints about low wages as beside the point - for there was no possibility of wages being raised

1 T. P. Whittaker at Manchester, October 23, 1893, ibid., October 27, 1893, p. 735.

2 Ibid., January 5, 1894, p. 7. 
without increases in productivity. The charitable schemes of philanthrophists were equally naive, for their short run alleviations of urban poverty would only deepen social misery in the long run. Only the genuine reform of prohibition could assuage the Condition of England question. The prohibitionists thus saw themselves as in an ideal position to arbitrate between the propertied and the laboring classes. Their message would be founded on the premise of self-improvement, assisted by a governmental ukase against the drinkshops. Once the state had ceased to tempt the worker with its licensed public houses, social tension would quickly moderate.

In the figure of William Hoyle, the prohibitionist camp produced one of the important second line economists of the Victorian period. Hoyle provided the temperance crusade with a defense of the economic wisdom of abstinence. He attempted to prove the existence of selfinflicted poverty through statistics, contending that only the spending habits of the working class were responsible for its destitution.

Hoyle was a self-made man, whose personal rise served him as the model for his later analysis of poverty. The "statistician of temperance" was born in Sumersent, Lancashire in 1831. Hoyle entered the cotton trade at the age of eight as a spinner. Eventually, he owned a mill at Tottington, employing $\mathbf{5 0 0}$ workers. Raised as a Wesleyan Methodist, Hoyle took the abstinence pledge at the age of fifteen. Apart from his unsuccessful campaign as a Liberal candidate for Dewsbury in 1880, Hoyle eschewed politics. His importance for the temperance cause lay in his distinctly moralistic interpretations of classical economy. His literary output was chiefly limited to tracts and his annual letters to the Times entitled "The National Drink Bill".

All of Hoyle's economic writings were pervaded by a feeling of an alcoholically induced catastrophe. By his estimation England had at least 600,000 drunkards - of whom $10 \%$ died annually of overdrinking. The full social cost of intemperance meant that at least onesixth of the population lived below the poverty line. ${ }^{1}$ In Hoyle's view, the ills of industrial England - unemployment, trade depressions, class tensions - grew from the one cancerous fact that while many cotton mills were running only nine hours a day because of slack demand, the public houses were open seventeen hours daily.

Hoyle saw the drink induced depression as the logical consequence of the morally permissive philosophy of laissez-faire. He considered that the great weakness of the laissez-faire ethic was regarding the attainment of wealth as the sole criterion for national existence. The necessary social discipline which would have insured moral progress

1 William Hoyle, Our National Resources and How They Are Wasted (London, 1871), p. 27. 
had been slighted. The banality of laissez-faire stood absolutely revealed by the drink curse:

"A doctrine which has done much to land the nation in its present position socially, for it taught that the forces of evil were not to be interfered with by government, except when the perpetrators of the evil were legally criminal." 1

Sin was thus the crucial economic factor in Hoyle's theory of commercial depression. Unemployment and falling profit margins sprang, not from impersonal economic laws, but from the moral failings of the working class. The wage levels of the English working class were sufficient to maintain domestic demand levels if focused upon legitimate consumption. The laboring classes could not be underpaid in Hoyle's view, if they could afford to spend ten times as much on alcohol as what they spent on cotton products.

In some passages, Hoyle seemingly argued for an under-consumptionist interpretation of England's commercial depression. By emphasizing the lack of "respectable consumption", he did indicate that insufficient consumption was causing a glut of unbought goods. But Hoyle denied that England was suffering from an over-production which was endemic to capitalism. He considered that only after all legitimate consumption demands had been satisfied, could overproduction be possible. Hoyle expressed concern that advanced Liberals such as John Morley and W. E. Forster had accepted the over-productionist fallacy.

Hoyle felt that economists erred in basing their theories upon monetary analysis rather than upon the moral character of the working classes. He argued that the reduced level of domestic consumption could have only two explanations: either there had been a sharp diversion of working class income into immoral consumption patterns or the economy had simply declined in overall wealth. The later possibility was obviously invalid; English wage standards were among the highest in the world. For Hoyle the explanation for stagnant trade lay in the simple fact that people could not squander their money on drink and put clothes on their backs at the same time. Hoyle: considered the drinker to be a "destroyer of wealth" - an individual whose vice lowered the wage fund and thereby cut the ability of

'William Hoyle, Our National Drink Bill (London, 1884), p. 182. Hoyle's overall view of the state, however, was not markedly different from that of the "Manchester School". He desired a limited state budget, feeling that the 1882 budget of 85 million pound could have been reduced by at least 20 million. Hoyle felt that soldiers and sailors should be partially employed as farm laborers in order to reduce their tax expense. 
society to employ labor. A drunkard did not receive anything of value for his wages spent upon drink. The equivalent sum expended on food would have fed him, giving him the sustenance with which to reproduce a value equal or greater to that which he had consumed.

Liquor was also hamstringing the economy because of its escalation of local taxation. The revenue which alcohol contributed to the Exchequer $(£ 30,000,000$ in 1880) was small recompense in Hoyle's eyes for the burden which drink was placing upon the urban ratepayer. The social costs of drink - welfare, crime, and insanity - were requiring ever higher levels of local taxation. Hoyle attributed at least two-thirds of the rates to the side effects of liquor. High taxation levels were consequently distorting the pattern of English industry. Manufacturers were leaving Manchester for areas of higher sobriety and lower taxes. What was true for regions was also becoming true for entire nations for investment was switching from England to more temperate lands. Eventually, the high expenditures on pauperism and crime must find their way into the price structure of British exports; England could simply not afford the tax burden of her drunkenness and survive the competition of foreign industry.

Hoyle's remedy was simple - to impose prohibition upon the working class and thereby reverse the decline in the savings function. He felt that a temperate working class would abandon its class hatreds as it progressed upward in the social scale. Eventually, the working sectors would adopt the cultural mores of the middle classes:

"Hence, manifestly as wealth accumulates by the thrift and temperance of the People, it places a greater share in their hands, and makes them more and more independent - even co-operative capitalists." 1

A substantial bloc of the socialist movement accepted the "moral" explanation of poverty as supplied by Hoyle and other prohibitionist businessmen. This circle of labour leadership saw the question of destitution through strongly evangelical spectacles; prominent within this group was the dynamic organizer of the London Dock Strike of 1889 , John Burns. Burns took an almost perverse pride in informing his working class audiences that their besetting sin was drunkenness. He considered moral self-improvement to be the first premise of democracy. Thus, the plight of the worker was due only to his "oxlike submission" - a condition which enabled the propertied classes to impose degradation upon him. The drinking habits of the working, sector had been deliberately fostered by the ruling classes:

1 William Hoyle, Wealth and Social Progress (Manchester, 1887), p. 188. 
"Drink is the Circean cup that is offered by a callous dominant class to those whom otherwise they could not enslave."1

Prohibition for Burns held a political content that was foreign to the circle of temperance manufacturers; however, both agreed that drunkenness was the chief cause of poverty.

Other labor leaders such as Will Crooks, Keir Hardie, and Arthur Henderson were in substantial agreement with Burns's position. These spokesmen agreed with Burns that alcohol was retarding the growth of working class radicalism in two ways. In the first place, constant drunkenness left the working man contented with his lot. Secondly, it was felt that intemperance was undercutting the effectiveness of strikes, for manufacturers were bringing in as strike breakers the shiftless sort who had previously been fired for drunkenness.

But by the late 1880's the "moral" explanation of poverty was subject to increasing criticism, both from within the socialist movement and from the left wing of Liberal Party. These critics shared little in common in either temperament or class background; men such as Robert Blatchford and John Hobson were united only by a common detestation of temperance as a desirable goal for the working class. By the late 1880's it became commonplace for agitators such as Tom Mann to enter public debates against prohibitionist speakers on the causation of poverty. ${ }^{2}$

Central to the attacks of socialists such as Mann or Blatchford upon temperance was their insistence that class lines were now frozen for the great majority of workingmen. By denying the possibility of meaningful social mobility, these critics were attacking the formula of self-advancement through respectability that had long been crucial to the prohibitionist cause. Increasingly, socialists labelled the temperance movement as merely the cynical front for the industrialists. Robert Blatchford, the colorful editor of the Clarion, argued that the workings of the iron law of wages would result in lower wages should working class abstinence ever be achieved. Blatchford considered the addiction of his class to liquor as the horrible but necessary means of preserving existing wage levels. The real villains of the drink question were not the drunken workers - nor even the publicans - but the:

"Grasping employers, the polluter of the river and the air, the jerry-builders, the slum lords, and the detestable knaves who

1 John Burns, Labor and Drink (London, 1904), p. 1.

2 Tom Mann to John Burns, March 16, 1888, Burns Papers, British Museum, Add. Mss 46285 , f. 6 . In his Memoirs Mann revealed that he had been both a teetotaler and a vegetarian in his youth and did not reject the prohibitionist explanation of poverty as "nauseous" until the 1880's. 
grow rich by the sale of poisoned and adulterated liquor."1

Blatchford felt the intemperance of the worker to be morally unfortunate, but stated that he should not be condemned until the social conditions that had produced that drunkenness had been alleviated:

"The gin - that hellish liquor which blurs the hideous pain of life, which stills the gnawing pain, which stays the crushing hand of despair, and blunts the grinding teeth of anguish when the child lies dead of the rickets, or the 'sticks' are sold for the rent. What would they do, these women, were it not for the devil's usury of peace - the gin."2

Those prohibitionist industrialists who protested their difficulties of competing with Indian cotton goods because of the drunkenness of the English worker were being inherently deceptive:

"The Indian workers live chiefly on rice and water and work for longer hours than do the English workers. And don't you see that if the Lancashire workers would live upon rice and water, the masters would soon have their wages down to the rice and water point."3

From the Liberal left J. A. Hobson provided the opponents of prohibition with a slashing economic indictment of prohibition. Hobson felt that the moral definition had outlived its usefullness - that its only remaining social role was to lighten the guilt of the prosperous classes. Hobson was convinced that morality could be preached to the working man only if his economic condition underwent prior improvement.

In Hobson's viewpoint, what was true for a single worker would not be correct for the working class as a whole. He admitted that if an individual laborer converted to abstinence, his economic picture would be improved. But if the entire labor force became abstainers, the result would be catastrophic for wage standards: unless a substitute craving could quickly be found, employers would cut wages down to a new and lower subsistence level. Hobson thus argued that since beer had become an accepted dietary staple for the worker, any turn to abstinence would only lower his wage packet: "To the ordinary laborer, beer is a part of the minimum subsistence for less than which he will not consent to work at all." 4 Hobson contended that while

1 Robert Blatchford, Merrie England (London, 1894), p. 157.

2 Robert Blatchford, Dismal England (London, 1899), p. 22.

3 Ibid.

4 John A. Hobson, Problems of Poverty (London, 1891), p. 172. 
prohibition would produce a more efficient work force, it would also mean a substantial increase in poverty. Only if an equally expensive demand - such as old age insurance, better housing, or more recreation - could be substituted could wage standards be maintained.

The emergence of the challenge to the "moral" interpretation of poverty was met by an outraged response by the prohibitionists. Characteristic was the charge of the Alliance News that the socialists must now be recognized as the open and aggressive enemy of the temperance movement:

"They teach doctrines of a most pernicious character - poisonous blockheadiness - which, if accepted, and they are likely to be accepted by the more credulous and less intelligent of the people, cannot fail to maintain and even to increase the evils which it is alleged socialism will remove."

Socialism thus held a terrible danger for the future of class relationships, as it preached rights instead of stressing duties.

The standard prohibitionist diagnosis of poverty in the 1890's continued to be that of Hoyle's - that the lower class had misused its wages and therefore had created its own misery. Redistribution of property could not change that moral flaw; new wealth without a prior change of habit would just increase the opportunities for dissipation. ${ }^{2}$ Temperance spokesmen exhibited little patience with the socialist contention that poverty caused drunkenness - alleging that if this were the case, then all of the poor would be drunk. Prohibitionists were revolted by the "extraordinary theory" that working class wages were sustained by liquor expenditure. ${ }^{3}$ The Church of England temperance writer, Clifford Oyston felt that even if the socialists were correct in their assertion that wages would decline because of prohibition, a good Christian must still put sobriety before his standard of living. 4

By the early 1900's, however, the temperance position on selfinflicted poverty had softened considerably; prohibitionist spokesmen were now willing to admit the widespread existence of "economic" poverty, i.e., poverty caused through no moral fault of the pauper. The Alliance propagandist, William Pearson, admitted that former temperance men had gone too far in diagnosing poverty as being exclusively moral in causation:

1 Alliance News, February 5, 1892, p. 88.

2 J. M. Skinner, Socialistic Theories and the Drink Traffic (London, 1896), p. 162.

3 Alliance News, December 23, 1892, p. 837.

4 Clifford Oyston, Socialism and the Drink Evil (London, 1909), p. 85. 
"We do not say that the poverty of an agricultural labourer, with a weekly wage of 10 s, or a London work girl, with much less is caused by drinking or could be cured by teetotalism, though we may hazard the assertion that a teetotaler with 10 s a week is better off than a drinker with 20 s a week who spends 11 s in liquor."1

Several causes contributed to the increasing mellowness of the temperance posture. The crushing Liberal defeat in 1895, due partly to the hostility of the liquor trade, clearly demonstrated the suicidal nature of prohibition as an electoral issue. More importantly, the working class family was plainly no longer drinking at the high consumption levels of the 1870-1890 period; per capita beer consumption by 1909 had declined to 26.1 gallons. $^{2}$

Correspondingly, attacks on the idea of self-inflicted poverty had lost much of its urgency by the 1900's. Ramsay MacDonald and Phillip Snowden, the chieftains of the Labour Party, took a compromising stance on the dispute. Their blend of a moral and economic interpretation of poverty would determine the Labour view on the licensing measures of the Liberal government in the 1906-1914 period. MacDonald contended that the working man was driven to drunkenness through exploitation:

"And next door to him there is the fearful and devilish temptation of the public house, with its flaring lights, its genial welcome, its boon companionship, and its abominable drug that makes the present unreal and throws an evil glamour over the minds of men."3

He felt, however, that the socialists must blend economic and moral reform together, in the realization that only a transformation of character could change the working class. Mere material reform would be valueless, for it would leave the worker sunk in greed and ignorance. MacDonald's cautious diagnosis of poverty smoothed his relationships with the ministers of the two major parties, particularily with the Liberals. He certainly regarded the liquor trade as a degrading occupation; in 1908 he pressed Herbert Gladstone to introduce legislation barring the employment of bar maids. ${ }^{4}$

Phillip Snowden also refused to be drawn into a categorical stance on the question of self-inflicted poverty. He admitted that the early

1 Alliance News, August 14, 1902, p. 522.

${ }^{2}$ Wilson, Alcohol and the Nation, p. 333.

${ }^{3}$ J. R. MacDonald, Character and Democracy (London, 1909), p. 45.

4 Ramsay MacDonald to Herbert Gladstone, April 8, 1908, Viscount Gladstone Papers, British Museum, Add. Mss 45986, f. 102. 
attacks of the socialists had often been unfair to the prohibitionist movement. The achievement of working class temperance would not seriously weaken the position of the capitalist. ${ }^{1}$ But Snowden regretted the tendency of many socialist spokesmen to ignore the drink question and to place the entire blame for deprivation upon the economic system. In Snowden's view, abstinence and socialism should co-exist; he desired the state to sponsor temperance propaganda aimed at working class youths. He noted wryly that the Labour Party was the living refutation to the stereotyped image of the drunken worker. Alcohol was sold in less than $3 \%$ of the ILP clubs; the great majority of Labour MP's were teetotalers. ${ }^{2}$

By 1914 the debate between the socialist and prohibitionist had become anachronistic. Even temperance circles now accepted the argument that the life of the English worker was stamped with dullness - and that in those circumstances, inebriation must occasionally be expected. The old statistical confidence of temperance men vis-a-vis poverty had evaporated. The temperance researchers, Rowntree and Sherwell, were more concerned with the eradication of poverty than with minute analysis of its causation. Sherwell concluded that even if bad housing conditions were the result of prior drinking habits, the temperance reformer had still to face the fact that slums existed. ${ }^{3}$ $\mathrm{He}$ felt that while diversions such as museums, meeting halls, and parks might not reform the hardened drinker, it would entice the young away from the public house. Political economy was no longer the reliable ally of temperance that it had been in the mid-nineteenth century. The neo-classicists, dismissing the wage fund concept as a clumsy abstraction, had little comment on the subject of working class dissipation.

Symbolic of the diminished importance of the question of selfinflicted poverty was the changed posture of Lloyd George on prohibition. During the 1890's Lloyd George had been a militant supporter of prohibitionist legislation; he had told an 1892 audience that alcohol was at the root of $90 \%$ of the crime in England. ${ }^{4}$ By 1907, however, Lloyd George, now head of the Board of Trade, supported the Board's survey of working class drinking habits. The report contended that working class drunkenness was no longer te sharp social question that it had been thirty years before. The report argued that the chief

1 Phillip Snowden, Socialism and the Drink Question (London, 1908), p. 82.

${ }^{2}$ There were occasional tremors in the truce. In 1908 the local Labour Party of Huddersfield opposed the Liberal Licensing Bill on the argument that if passed, the temperance measure would increase unemployment.

${ }^{3}$ Arthur Sherwell, Counter Attractions to the Public House (London, 1911), p. 5.

4 Alliance News, October 24, 1890, p. 697. 
reasons for this transformation of habit were education, greater recreational facilities, improved sanitary conditions - and in a "few cases" the influence of the temperance movement. ${ }^{1}$

The belief in self-inflicted poverty thus lapsed into obscurity as did its parental code of respectability. But in its Victorian heyday, the question of causal responsibility for poverty and drunkenness had seemed both a live and vital topic.

1 Memorandum as to Drink and Drinking Habits Among the Working Classes, November 20, 1907, Public Record Office, Cab. 37/90. 